\title{
A PRAGMATIC STUDY ON THE SERVICE GAP ANALYSIS OF AN INDIAN PUBLIC SECTOR BANK
}

\author{
Rengaswamy NALINI ${ }^{1}$, Ramachandran AMUDHA ${ }^{2}$, \\ Venkatarayareddiar SUJATHA ${ }^{3}$, Rengaswamy RADHA ${ }^{4}$ \\ ${ }^{1,3,4}$ Cauvery College for women, Tiruchirappalli, Tamilnadu, India \\ ${ }^{2}$ School of Management, SASTRA University, Thanjavur, Tamilnadu, India \\ E-mails: ${ }^{1}$ nalini.cauvery@yahoo.com (corresponding author); \\ 2amudha@mba.sastra.edu; ${ }^{3}$ cauverycollege_try@rediffmail.com; ${ }^{4}$ akshyaamudha@yahoo.com
}

Received 13 January 2014; accepted 01 July 2014

\begin{abstract}
Customers are the major stakeholders and their satisfaction forms the basis of the sustainable competitive advantage of the firm. Attracting, satisfying and retaining customers lead to extended customer base and increased profit margins. Thus, the customer satisfaction is the ultimate objective of the firm which is possible by rendering quality service. The State Bank of India (SBI) ranks as $67^{\text {th }}$ in the list of largest banks in the world based on market capitalization as of March $31^{\text {th }} 2014$. The quality of service extended by the SBI has resulted in customer satisfaction and expanded customer base for the bank. Random sampling method is adopted for the collection of data from the respondents. In Tiruchirappalli regional office of State Bank of India, area operations are selected within 10 Kilometer radius from the Main branch and 60 questionnaires per branch have been distributed in 10 branches. Out of 600 questionnaires, 109 are found incomplete and 491 are fully complete with $81.83 \%$ of response rate. The data collected were analysed with the help of MS Excel to identify the gaps. The Cronbach alpha, a measure of internal consistency obtained is 0.925 which is considered to be excellent. This study aims to identify the gaps in the dimensions of service quality by administering SERVQUAL model among the customers in State Bank of India. An overall weighted SERVQUAL score of -1.42866 was arrived, representing a significant inconsistency in meeting customer expectations across all service dimensions. Highest gap scores for reliability and empathy depicts that there is a need for courtesy and politeness among SBI employees which in turn will help to establish a long term relationship with the customers. The relatively low gap scores were found for responsiveness, tangibles and assurance dimensions. The State Bank of India has to take steps to close the gaps and it can be closed by establishing and implementing a service quality information system.
\end{abstract}

Keywords: service quality, tangibles, reliability, responsiveness, assurance and empathy.

JEL Classification: M31.

\section{Introduction and design of study}

In the highly competitive market today, the major aim of any organisation is to earn more profits and contribute to the wealth maximisation. Customers are the major stakeholders and their satisfaction forms the basis of the sustainable competitive advantage of the firm. Attracting, satisfying and retaining customers lead to extended customer base and increased profit margins. Thus, the customer satisfaction is the ultimate objective of the firm which is possible by rendering quality service. Service quality is the interaction between the customer and the service provider. Service quality is determined by the service delivery performance of a firm. If the expectations equal the perception, the customers are satisfied and vice versa. Customers rate their expectations of service from an excellent organization, and then rate the performance they receive from the organization.

SBI ranks as $67^{\text {th }}$ in the list of largest banks in the world based on market capitalization as of March $31^{\text {th }} 2014$. It

Copyright $\odot 2014$ The Authors. Published by VGTU Press.

This is an open-access article distributed under the terms of the Creative Commons Attribution-NonCommercial 4.0 (CC BY-NC 4.0) license, which permits unrestricted use, distribution, and reproduction in any medium, provided the original author and source are credited. The material cannot be used for commercial purposes.

To link to this article: http://dx.doi.org/10.3846/btp.2014.415 
has a market capitalization of US $\$ 24.008$ billion as on $31^{\text {st }}$ March 2014 (Banks around the world 2013) with the symbol as NSE: SBIN. There are 228,296 employees in SBI as on March $31^{\text {st }} 2013$ (SBI 2014a). SBI has 13,000 branches with 5 associate banks including 190 foreign offices in 36 countries (SBI 2014b) and assets worth of US\$ 17922.34 billion as on March $31^{\text {th }} 2014$ (Moneycontrol.com 2013). The world's leading provider of global business information, knowledge and insight, Dun \& Bradstreet (D\&B), announced "Dun \& Bradstreet-Polaris Financial Technology Banking Awards 2013" in Mumbai and declared SBI as the Best Public Sector Bank (D\&B 2013). An excellent customer service enhances productivity, develops employee morale, financial performance and profitability and leads to increased market shares.

Random sampling method is adopted for the collection of data from the respondents. In Tiruchirappalli regional office (situated in Tamilnadu with Chennai as headquarters) of SBI, area operations are selected within 10 kilometer radius from the Main branch and 60 questionnaires per branch have been distributed in 10 branches. Out of 600 questionnaires, 109 are found incomplete and 491 are fully complete with $81.83 \%$ of response rate. The data collected were analysed with the help of MS Excel to identify the gaps. The Cronbach alpha, a measure of internal consistency obtained is 0.925 which is considered to be excellent.

Banks play a significant role in the economic development of the nation. Increased competition, improved sophistication of customers and technological up gradation have forced the banks to be highly efficient and effective in delivering service. Customer is the centre focus and he/she is the final decider of the success of any organisation. The customer has a wide range of banks to choose based on services rendered and this paves the way for the shifting of demand from one bank to another. Only if customer is satisfied, it will facilitate a bank to retain them and attract new customers. The increased customer base over the years will convey the quality of service and the resultant customer satisfaction. Service quality can be concisely defined as the personal experience of the customer with the service provider. This study aims to identify the gaps in the dimensions of service quality by administering SERVQUAL model among the customers in State Bank of India.

\section{Review of literature}

Zeithaml, Parasuraman and Berry (1996) have revealed that empirically established service quality improvement with behavioural intentions i.e., a service provider can expect the consumer's behaviour to be favourably inclined to a company, which provides improved service quality. Tuncikiene et al. (2014) have revealed that the contemporary society expects effective work and high quality of the public sector which causes change in operations of instuitions and companies. Forda (2001) revealed that customers who expect relationships with providers tend to expect personalized service communication from those providers.

Choudhury (2007) suggested that customers differentiate attitude, competence, tangibles and convenience among other variables in service quality. Jackson et al. (2003) said that the competitive structure of the banking sector and the ability to cope with the innovations in service quality will decide the option of the customers to choose a particular bank. Jain and Gupta (2004) have revealed that customer satisfaction results when perceived service quality is more than expected service quality and vice versa. Lenka et al. (2009) have revealed that in the Indian banking sector, human aspects are more important than technical and tangible aspects of service quality that influence customer satisfaction and promote and enhance customer loyalty.

Nadiri et al. (2009) have stated the loyal and valued customers can be retained in banks by rendering elevated service quality. Khare, Parveen and Rai (2010) have said that the employee is considered important in building successful relationships with the customers in retail sector. Bhusan, Kumar (2011) suggested that the PZB Service Quality Model is an effective tool to identify gaps in the service conceptualization, designing and delivering process. Reduction of gaps in the transaction of service between service provider and customer is of critical importance as it affects the customer satisfaction level, customer retention probability and long term financial leverage of the service firm. The study identified service quality gaps in the service transaction process between some selected branches of State bank of India, Kolkata, and its customers.

Ravichandran, Bhargavi, Arun Kumar (2010) have made a study among the respondents from two major public banks of Tiruchirappalli city of Tamilnadu, India. Tangibility, responsiveness and empathy play a significant role in the behaviour of customers. Ganesh and Nandagopal (2011) have found that the dissatisfaction and non-committal attitude of the customers in retail banking sector is due to the gap between the expected and perceived service levels.

Amudha and Vijayabanu (2012) have stated that the service encounters is the first stage where the customers judge the service quality extended to them. Roy, Vaijayanthi, Shreenivasan, Preetha, and Shivangi (2012) have stated that a customer relationship is successful only when there is a perfect combination of technology and competence of human resource. This will result in customer satisfaction and loyalty in banking sector. Verma, Chaudhuri (2008) have stated that the nature of banking in India is passing through a transformation, due to recent changes in economic, business, legislative, technological and social environments. As a result of the growing level of competition and the rapid pace of change, customer orientation is emerging as an important element in the banking sector. Zvireliene and 
Buciuniene (2008) have stated that a company that seeks to earn the customer loyalty and maintain a competitive advantage has to be well versed in the qualitative dimensions of relationships. Amudha, Surulivel and Vijayabanu (2013) have stated that satisfaction of employees' mainly depends on the internal service quality in an organization which ultimately results in the customer satisfaction and their loyalty towards the organizations.

\section{Analysis and discussion}

The inseparability and intangibility nature of services makes the process of delivery more important than delivering a product. Services sector faces a unique challenge of remaining competitive by meeting the needs of customers with optimum mix of technology and people. Service quality can be concisely defined as the personal experience of the customer with the service provider. The customers always try to strike a balance between service and efficiency and decide to place trust and confidence on the bank. Customer satisfaction is the good indication of loyalty towards the bank. This customer satisfaction depends on five main dimensions of quality namely, tangibles, reliability, responsiveness, assurance, and empathy.

This Gap model discusses the fourteen gaps and the ways in which these gaps can be closed with the help of five service quality dimensions. Gap five relates to the consumer and it is the real gap to study the expected service and perceived service. It has a direct relationship with the customer and it is treated as an external gap. The other thirteen gaps are treated as internal gaps arising among different departments within the organization. All the thirteen gaps are related with the service provider who has to take real steps to maintain a relationship with the customer. The service provider has to realize the causes for gaps and remedial measures to be taken to fill up these gaps. The following

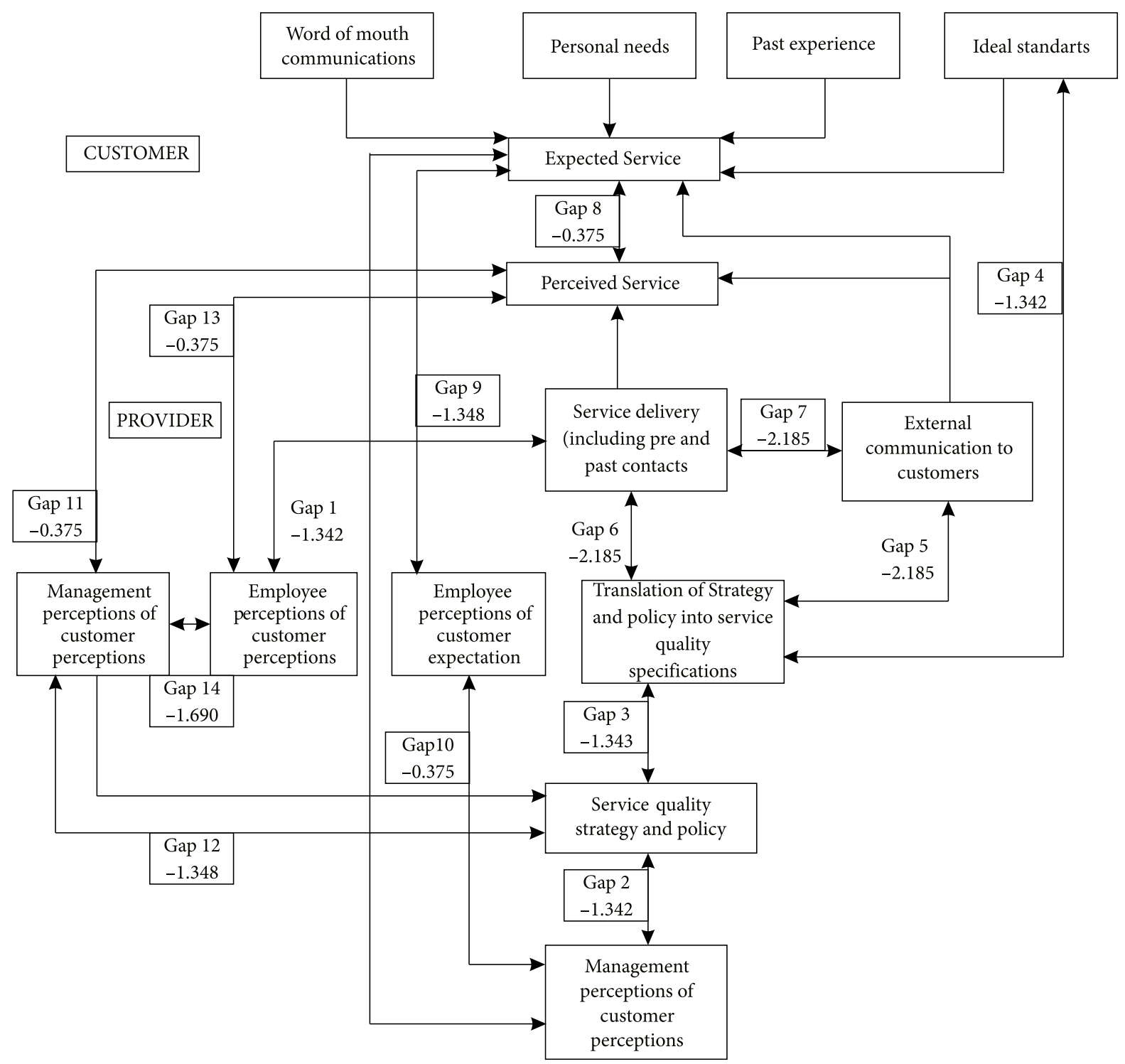

Fig. 1. Service quality gaps model (Source: Shahin, Samea 2010) 
gap model (Fig. 1) shows the gaps in delivering service by SBI branches under study.

The Banking Ombudsman Scheme (BOS) was introduced by Reserve Bank of India in the year 1995 with a view to provide expeditious and inexpensive redress of customers' grievances against deficiencies in banking services provided by Commercial banks, Scheduled Primary Co-operative Banks and Regional Rural Banks. A customer can complain to Offices of Banking Ombudsman (OBO) against deficiencies in banking service including credit cards, ATM, internet banking and non-adherence to the provisions of the Fair Practices Code for lenders or the Code of Bank's commitment to customers issued by the Banking Codes and Standards Board of India (BCSBI). In India, fifteen OBOs covering 29 states and 7 Union Territories handle the complaints received from bank customers and they have received 70,541 complaints during the year 2012-13. Of the total complaints received, individual customers constitute $93 \%$ and $72 \%$ from urban and metropolitan cities. Of the total complaints received during the year, $10.28 \%$ was received by Chennai OBO standing next to New Delhi (13.39\%), Kanpur (12.78\%), and Mumbai (12.20\%). Of the total complaints received, SBI Associates tops the first (33\%) followed by nationalized banks (31\%) and private sector banks (22\%). $26 \%$ of the total complaints was related to failure to meet commitments and non-observance of fair practices code and BCSBI Codes and $25 \%$ was related to ATM, credit and debit cards. The complaints regarding non-observance of Codes is due to the lack of awareness about the Codes among the bank staff and customers. The reason behind the complaints over the cards is due to the issue of unsolicited cards, sale of unsolicited insurance policies and recovery of premium, charging of annual fee in spite of being offered as free card, authorization of loans over phone, wrong billing, settlement of offers conveyed telephonically, non-settlement

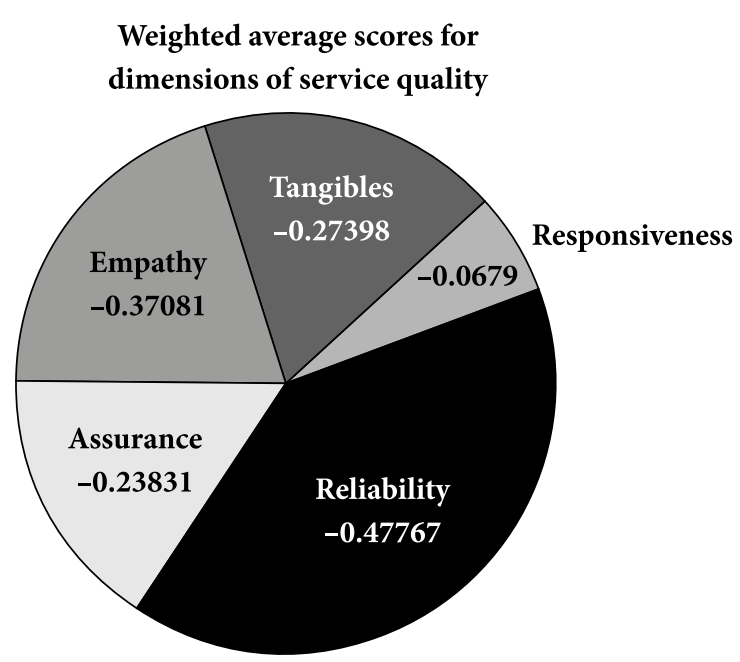

Fig. 2. Weighted Average scores for Dimensions of service quality (Source: Primary data) of insurance claims after the demise of card holder, excessive charges, wrong debits to account, non-dispensation/short dispensation of cash from ATM and skimming of cards (Annual Report on Banking Ombudsman Scheme 2012-13 (Reserve Bank of India 2014)).

Hence, the study aimed to know the gaps in the dimensions of service quality of SBI and the results are discussed in as follows:

Table 1. SERVQUAL scores for banking services offered by State Bank of India (Source: Primary data)

\begin{tabular}{|c|c|c|c|c|c|}
\hline 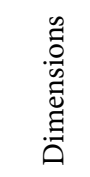 & 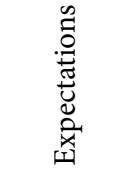 & 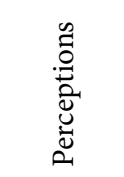 & 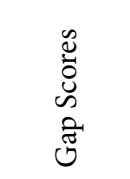 & 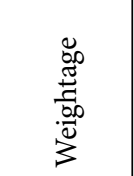 & 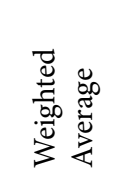 \\
\hline $\begin{array}{l}\text { Tan- } \\
\text { gibles }\end{array}$ & 24.2831 & 22.94094 & -1.34216 & 20.41314 & -0.27398 \\
\hline $\begin{array}{l}\text { Relia- } \\
\text { bility }\end{array}$ & 26.3869 & 24.20163 & -2.18534 & 21.8578 & -0.47767 \\
\hline $\begin{array}{l}\text { Res- } \\
\text { pon- } \\
\text { sive- } \\
\text { ness }\end{array}$ & 21.1323 & 20.75764 & -0.37474 & 18.11803 & -0.06790 \\
\hline $\begin{array}{l}\text { Assu- } \\
\text { rance }\end{array}$ & 21.1222 & 19.77393 & -1.34827 & 17.67541 & -0.23831 \\
\hline $\begin{array}{l}\text { Em- } \\
\text { pathy }\end{array}$ & 26.2220 & 24.53157 & -1.69043 & 21.9356 & -0.37081 \\
\hline $\begin{array}{l}\text { Over } \\
\text { all }\end{array}$ & 119.1467 & 112.2057 & -6.94094 & 100.00 & -1.42866 \\
\hline
\end{tabular}

It is obvious from above Table 1 and Figure 2 that all the responses were negative and an overall weighted SERVQUAL score of -1.42866 was arrived, representing a significant inconsistency in meeting customer expectations across all service dimensions. The scores for each dimension are summarized in above table, with the weighted average scores per dimension having been added to achieve the overall SERVQUAL score. Shreenivasan et al. (2012) have revealed that the inter correlation among the dimensions of SERVQUAL highlights the importance of reliability and assurance in the Indian banking sector. It can be seen from the table that the highest gap scores were for Reliability and respondents have allocated the utmost weighting to reliability. This is the main reason for due consideration and provides an explicit starting point for improvement in services. As can be seen from the results, the respondents expect most from the reliability dimension of the banking service. The respondents are not satisfied with the possibility of the promises, the problem handling devices and provision of error free services by the State Bank of India.

The next highest gap scores were for empathy and the respondents has allocated the highest weighting to empathy. Each respondent has a share of meetings with a rude 
employee in a bank counter at some point of time. The experience leaves a sour taste and makes one reluctant to visit the place again. It is important to make sure that the respondents do not feel the same way about bank. Showing courtesy and politeness when the bank interacts will show that consumers are important and help establish a long term relationship. The respondents are not satisfied with the guidelines, systems and procedures of the organization. Empathy is the keyword to make the extra effort to explain to him clearly and in simplest of terms and conditions of State Bank of India. Bhat (2005) has revealed that dearth in tangibility and responsiveness is the major reason for the low level of service quality among Indian banks. The relatively low gap scores of responsiveness could be attributable to the fact that respondents are satisfied with the behaviour of representatives and officials of the bank. The relatively low importance of tangibles could be attributable to the fact that respondents are less satisfied with physical facility, equipment and appearance of personnel. The respondents are also of the opinion that the SBI is not concentrating on the physical facilities like sitting facilities, parking facilities, interior decors and the like. Respondents have allocated assurance the lowest weighing, indicating it to be of least importance to them, yet they expect most from this service dimension.

\section{Recommendations to fill the gaps}

Pranic, Roehi (2012) have stated that the intangibility of banking services makes the evaluation of service quality and customer convenience difficult to measure. Tuncikiene and Buzaite (2010) have stated that functional analysis is essential in public sector as it assures high quality of public services and minimal possible costs.

Tangibles represent the physical facilities of the bank, reliability shows the ability of the employees to perform the accurate service, responsiveness reveals the willingness of the employees to render prompt and quality services, assurance means the ability of the employees to instigate trust and assurance of the customers and empathy means the kind and individual attention of the employees towards customers. These five dimensions of the service quality can be used to fill the fourteen gaps and the following Table 2 shows the relationship of the same.

Tangibles: The dimension tangibles can be attributable to the first four gaps namely, knowledge gap, quality strategy gap, specification gap and standard gap. These gaps can be closed by the way of designing and developing right service quality standards through the emphasis on the tangibles. The knowledge gap (Gap: 1) is the difference between management perceptions about the customer expectations and the real expectations of the consumer in market. This gap is mainly due to inadequate market information and
Table 2. Relationship between dimensions of service quality and gaps (Source: Primary data)

\begin{tabular}{|l|c|c|}
\hline \multicolumn{1}{|c|}{ Dimensions } & Gaps & $\begin{array}{c}\text { Weighted } \\
\text { Average }\end{array}$ \\
\hline Tangibles & $1,2,3,4$ & -0.27398 \\
\hline Reliability & $5,6,7$ & -0.47767 \\
\hline Responsiveness & $8,10,11,13$ & -0.06790 \\
\hline Assurance & 9,12 & -0.23831 \\
\hline Empathy & 14 & -0.37081 \\
\hline Over all & -- & -1.42866 \\
\hline
\end{tabular}

too many layers of management resulting in poor upward communication. This can be filled by collecting market information through planned formal and informal marketing research, collecting information from the industrial organization and from the competitors. The Quality strategy gap (Gap:2) arises due to the improper formulation of strategies for maintaining service quality for the management and their perception about the customer expectation. This can be filled through a formulation of proper strategy regarding service quality by the management by taking into account the primary information collected from the market and from the competitors. This will help the SBI to benchmark the strategy in the market and to be a pioneer in the market.

The Specification gap (Gap: 3) arises when the formulated strategies are translated into service quality specifications. Proper translation can be had by adopting techniques of quality management and control. This gap may also be due to unwillingness of the employees of the organisation to implement the service specifications. The specification derived should be such that it is easily understandable by the employees as they are the persons to implement. The standard gap (Gap: 4) is due to inadequate standardization of the service process and a wrong perception of the quality of service. The specification of the service process determined should be properly standardized and converted into ideal standard. These ideal standards should be the goals to be achieved by the employees, as it will definitely meet the expected service of the consumers in the market. Khurana (2013) has found that there is a huge gap in tangible dimension and low gap in case of competency.

The first step is to identify the expectations of the customers through market research and complaint handling mechanisms. The next step is to increase the direct relationship between the organization and the customers. The third step is to establish the service quality standards. The service quality standards can be established by ensuring top management's commitment to establish elaborate service quality goals to meet customer expectations, inducing the middle level management to set, communicate and 
emphasize service standards for customers, training the employees to be receptive to modern ways of overcoming the barriers of service delivery, standardizing the service delivery process to ensure consistency and reliability, clarifying the employees regarding the priorities of the tasks to be performed through the considerate and accepting of goals to be achieved and satisfying the middle level management and employees for attaining the goals. Meghalaya Times reporter wrote on $23^{\text {rd }}$ February 2014 that green channel concept (GCC) is still a new concept to many customers in Shillong. Green channel counter or GCC facility was introduced by SBI on July $1^{\text {st }} 2010$ that is on SBI's $204^{\text {th }}$ birth anniversary and won "Best Customer Initiative" award at Indian Banks' Association (IBA) Banking Technology Awards 2010 (Meghalaya Times 2014). This was introduced to make paperless transactions like cash deposits; cash withdrawals and funds transfer with the maximum limit of 40,000 rupees with the help of Transaction Pre Processing Device (TPD). The customer can complete the transaction within a minute while the normal branch transaction takes two to four minutes for completion. The respondents at Tiruchirapalli also are not fully aware of this green channel counter and other schemes offered by the SBI. The major dissatisfaction shown by the respondents is that the bank concentrates only on the high income group. They also are of the opinion that SBI should concentrate on all segments of customers. The respondents are of the opinion that the internet banking is not working properly and it is not up to their satisfaction.

Reliability: This dimension is associated with fifth, sixth and seventh gap namely, internal communication gap, delivery gap and external communication gap.

The Internal communication gap (Gap 5) is due to the improper communication among employees within the organization and the tendency of overstating the promises. This can be filled by training the employees to think from the customer's perspective and to properly communicate and the specification of the service quality to the customer. The Delivery gap (Gap 6) is due to inappropriate teamwork and improper mapping of technology and the employees' position. This is also due to improper monitoring of the performance of the employee and inefficient control of the supervisor. This can be filled by increasing the effectiveness of supervision and control, training and rewarding the employees which will result in efficient delivery of service quality specification to the customers.

The External communication gap (Gap 7) is due to the improper communication by the frontline employees about the service delivery to the customers. The frontline service employee should be given proper training in communicating the service specification to the customers. This will help the customers to get knowledge about the service of the organization. It is suggested that SBI employees should make full rapport with customers; this will develop a social banking environment. The SBI employees should be given training from time to time to match their skill level with the requirements of changing environment. At least they should make aware about all the schemes provided by the banks. Special care is needed to manage customer relations effectively to make them satisfied with the working conditions, culture etc., so that, they can further provide best services to the valuable customers. Ahmed (2011) has conducted a survey among the customers of SBI in Garo Hills of Meghalaya and he has revealed that the gloomy service quality, inadequate knowledge of employee regarding bank services and locational inconveniences are the major reasons for the gap formed in the communication.

In Tiruchirappalli branches, the employees provide a slow delivery of quality service to the customers. The SBI in cities and metros need to improve on the quality of the services. The customers are more in number when compared to bank officials in all branches which results in the delay in rendering service. These branches have only two-three counters to render the service to the customers.

Most of the respondents prefer SBI for the safety of the hard earned money in their life time. The quality of the service offered by the bank and the level of confidence the public have placed on the bank as a Government of India undertaking has made most of the respondents to prefer state bank of India when compared to the other banks.

They revealed that more salaried transactions, pension transactions, simple interest funds, fixed deposits, money for jewel transactions happen consistently. Each respondent in these branches has undergone a share of meetings with a rude employee in a bank counter at any one point of contact with them. This experience leaves a sour taste and makes one reluctant to visit the bank and face the employee again.

Responsiveness: This dimension is concerned with eighth, tenth, eleventh and thirteenth gaps like Customer's perception gap, Management - Employee perception gap, Management - Customer perception gap and Employee Customer perception gap.

This Customers' perception gap (Gap 8) is due to the difference between the expectation and perception of the customers. The expectations of the customers are influenced by their previous purchases, word of mouth and the media. It differs with time, type of service, need and organization. The perception of the customers is influenced by efficient service delivery process by an organization. This can be filled by measuring service delivery performance and trained to match with the expectations of the customers. It is the actual challenge faced by the organisation and as it is the only external gap to be filled with obviously, it is the ultimate goal of the any organization to perfectly synchronize the expectation and perception of the customers which result in customer satisfaction. 
The Management - Employee perception gap (Gap 10) is due to improper understanding between perception of management and employees about the customers' expectations. To fill the gap the management should take adequate steps to educate the employees to be in line with management perceptions. This is so because the management perceptions are formulated based on marketing research. Transparency should be maintained by the management in convincing the employees about the customer expectations. Otherwise, the employees may doubt the management as it is taxing them in achieving the goals. If they are satisfied about the perceptions of management, there will be proper coordination between management and employees in achieving the goal. The Management - Customer perception gap (Gap 11) is due to the difference between customers' perceived service and management perceptions of customers' perceptions. To fill this gap efficient service strategy should be formulated to understand customers' expectations and perceptions. This will help the management to choose appropriate strategy to avoid wrong management decisions. This will help to achieve the customer satisfaction finally.

The Employee - Customer perception gap (Gap 13) exists between customers' perception and employee's perception of customers' perception. This can be filled by improving the ability of the employees and making the employees understand the customer expectation and perception. This is possible only through developing a cordial relationship between customers and employees through efficient management of human resource management.

The respondents' expectation and customers' loyalty in competitive environment is a prime factor to be reckoned with. It is important that banking get a 360 degree view of their customers. This will allow banks to have a deeper understanding of the customer's interaction with the various sections of the bank. The SBI needs analytics that can help them predict customers' interest in them as well as score cards that indicate how well they are performing against their goals.

Ravi and Basavaraj (2013) have found that in value added services, customer preference for net banking was least ranked and also states that if the bankers with to increase net banking traffic, bankers should take maximum steps to educate the customers by offering on line training instead of handing out instruction manuals.

The respondents have lack of knowledge about computerization, e-channels and these are the most dominating problems faced by them. Insufficient number of ATMs and lack of infrastructure are also major problems faced by the respondents.

Assurance: The dimension assurance can be attributable to the ninth and twelfth gaps namely interpretation gap and service strategy gap.
The Interpretation gap (Gap 9) is due to misinterpretation of the customer expectations by the frontline service providers. This can be filled by effective communication between the frontline service providers and consumer. The specialist in communication should monitor the external communication made by the provider before they reach final customers. If gap 11 is not filled, Service strategy gap (Gap 12) occurs. It is the gap between management's perception of customers' perceptions and service strategy.

The SBI staff must be educated to recognize the customers' behaviour, so that they may provide good customer service. The SBI staff should disclose the full information to the customers to win their confidence like service charges, service tax, interest penalty and the like. The respondents feel that the indifference in the attitude of the SBI staffleads to poor customer service and it is the gap in the process of delivering of service. They are of the opinion that existing customer service should be improved and the improvement in customer service will bring more satisfaction and loyalty towards SBI.

Empathy: This dimension is related with fourteenth gap like personnel relationship gap.

The Personnel relationship gap (Gap 14) exists between management's perception of customers' perceptions and employee's perception of customers' perceptions. This can be filled by an effective internal personnel relationship between the managers and employees. The managers should receive feedbacks from the employees about their perception and encourage them to collect information on the customers' expectations and perceptions.

People are the living, thinking and feeling beings that constitute the internal, social human sub-system of an organization. It requires planned and systematic approach for procuring, developing and managing work force in order to achieve organizational objectives in an effective manner. Bank's concern for development of the human resources through exposure to various responsibilities and recognition of their ability through various promotional facilities is clearly discernible. The respondents do not know the complete rules, regulations and procedures of the SBI and bankers preserve them for themselves and do not take interest in educating the customers. There is a need to educate the customers from the grassroots of banking.

\section{Conclusions}

A satisfying buyer/seller - interaction creates a sense of loyalty in the customer towards the organization. Able and willing employees aided by proper process can render best customer service which in turn will result in satisfied and loyal customers. Sujatha, Nalini (2012) have stated that Customer relationship results in better margins with enhanced customer satisfaction and reduced administrative 
costs. As retaining customer is cheaper than finding a new one, it is imperative to give emphasis on relationship banking and effective interactive marketing.

The State Bank of India has to take steps to close the gaps and it can be closed by establishing and implementing a service quality information system. The customer feedback can be collected through complaint analysis, mystery shopping, total market surveys and capture of service operating data. There should be a cell to monitor the work culture within a bank and the staff should be properly trained, motivated and educated for the services of the banks, as an organization can meet the customers' expectations only if the employees are efficient. Marketing, operations, and human resource managers need to communicate with one another to ensure that they can deliver quality experiences more efficiently.

Joshi, Awasthi and Jinnah (2000) have stated that enhanced customer service and satisfactory accomplishment of the expectations of the customers through innovative approaches leads to the success of the banks. SBI staff should be right sized (instead of down sized) to deal with customers effectively, efficiently and appropriately. The respondents are not satisfied with the technological developments like electronic banking channels ie., ATMs, internet banking, mobile banking and green channel counters. SBI is able to provide single window system to their customer, where all the needs of the customer are taken care of at a single counter. But this single window system has not reached the respondents successfully. The SBI should make personal contacts with demo at the counter and any other information and to make more and more customers aware about e-banking services, as they think these methods are most effective to cover this path.

The employees of the SBI should be properly educated to understand and execute the process of service delivery. The SBI employees should identify the problems of the customers and help them to solve systematically by establishing standard service performance measures. Periodical evaluation of the performance measures should be made the bank and measure customer satisfaction perpetually.

\section{References}

Ahmed, J. U. 2011. Services rendered by commercial bank: a customer oriented empirical evidence from State Bank of India, Management Convergence 1(2): 63-82.

Amudha, R.; Surulivel, S. T.; Vijayabanu, C. 2013. An impact of intermediaries' behaviour on customer satisfaction in an Indian private sector bank, International Journal of Engineering and Technology 5(6): 4613-4621.

Amudha, R.; Vijayabanu, C. 2012. A review of customer satisfaction towards service quality of banking sector, Social and Management Sciences Periodica Polytechnica 20(2): 71-19. http://dx.doi.org/10.3311/pp.so.2012-2.02

Banks around the world [online], [cited 8 January 2013]. 2013. Available from Internet: http://www.relbanks.com/worldstop-banks/market-cap
Bhat, M. A. 2005. Correlates of service quality in banks: an empirical investigation, Journal of Services Research 5(1): 77-99.

Bhusan, P. B.; Kumar, B. A. 2011. Application of PZB service quality model in identifying service quality gap - a study on State Bank of India, Siddhant - A Journal of Decision Making 11(1): 1-10.

Choudhury, K. 2007. Service quality dimensionality: a study of the Indian Banking Sector, Journal of Asia-Pacific Business 8(4): 21-38. http://dx.doi.org/10.1300/J098v08n04_03

Dun \& Bradstreet (D\&B). 2013. Media release [online], [cited 8 January 2013]. Available from Internet: http://www.dnb. co.in/News_Press.asp?mid=317

Forda, W. Z. 2001. Customer expectations for interactions with service providers: relationship versus encounter orientation and personalized service communication, Journal of Applied Communication Research 29(1): 1-29.

http://dx.doi.org/10.1080/00909880128098

Ganesh, P.; Nandagopal, R. 2011. Determining the gap between customer expectation and perception in retail banking, International Journal of Research in IT, Management and Engineering 1(3): 390-404.

Jackson, W. E.; Nandakumar, P.; Roth, A. V. 2003. Market structure, consumer banking, and optimal level of service quality, Review of Financial Economics 12(1): 49-63. http://dx.doi.org/10.1016/S1058-3300(03)00006-5

Jain, S. K.; Gupta, G. 2004. Measuring Service Quality: SERVQUAL vs. SERVPERF Scales, Vikalpa: 29(2): 25-37.

Joshi, J. K.; Awasthi, B. D.; Jinnah, M. M. 2000. Customer expectations and level of satisfaction from the Banking services: an empirical investigation, in Report of the UGC Sponsored Seminar on Liberalization and Role of Nationalised Banks, 6-7 January 2000, Kumaun University, Nainital.

Khare, A.; Parveen, C.; Rai, R. 2010. Retailer behaviour as determinant of service quality in Indian retailing, Journal of Retail \& Leisure Property 9: 303-317. http://dx.doi.org/10.1057/rlp.2010.14

Khurana, S. 2013. Analysis of service quality gap in Indian banking industry, The IUP Journal of Bank Management XII(3): 58-72.

Lenka, U.; Suar, D.; Mohapatra, P. K. J. 2009. Service quality, customer satisfaction, and customer loyalty in Indian Commercial Banks, Journal of Entrepreneurship 18(1): 47-64. http://dx.doi.org/10.1177/097135570801800103

Meghalaya Times. 2014. Green Channel Counter: still a new concept for many customers [online], [cited 23 February 2014]. Available from Internet: http://meghalayatimes.info/ index.php/front-page/22734-green-channel-counter-still-anew-concept-fpr-many-customers

Moneycontrol.com. 2013. State Bank of India [online], [cited 8 January 2013]. Available from Internet: http://www. moneycontrol.com/financials/statebankindia/balancesheet/SBI

Nadiri, H.; Kandampully, J.; Hussain, K. 2009. Zone of tolerance for banks: a diagnostic model of service quality, The Service Industries Journal 29(11): 1547-1564. http://dx.doi.org/10.1080/02642060902793425

Pranic, L.; Roehi, W. S. 2012. Rethinking service recovery: a customer empowerment (CE) perspective, Journal of 
Business Economics and Management 13(2): 242-260. http://dx.doi.org/10.3846/16111699.2011.620137

Ravi, C. S.; Basavaraj, K. 2013. Customers preference and satisfaction towards banking services with special reference to Shivamogga District in Karnataka, TRANS Asian Journal of Marketing \& Management Research 2(1): 28-38.

Ravichandran, K.; Bhargavi, K.; Kumar, S. A. 2010. Influence of service quality on banking customers' behavioural intentions, International Journal of Economics and Finance 2(4): 18-25.

Reserve Bank of India. 2014. Annual Report on Banking Ombudsman Scheme 2012-13 [online], [cited 1 March 2014]. Avfailable from Internet: http://www.rbi.org.in/scripts/ PublicationsView.aspx?id=15718

Roy, R.; Vaijayanthi, P.; Shreenivasan, K. A.; Preetha, H.; Shivangi, S. 2012. An empirical study on CRM as a tool to assess customer satisfaction for banks - a comparison public sector banks with private sector bank, in Proceedings of Management Issues in Emerging Economies (ICMIEE) Conference, 17-18 August 2012, SASTRA Univerity, Thanjavur, Tamilnadu, India, 90-94.

Shahin, A.; Samea, M. 2010. Developing the models of service quality gaps: a critical discussion, Business Management and Strategy 1(1: E2): 1-11.

Shreenivasan, K. A.; Vaijayanthi, P.; Karpaganathan, R. 2012. Service quality perceptions - an empirical study of SERVQUAL and customer satisfaction in the banking industry, Journal of Innovative Research Sloutions 1(1): 89-101.

State Bank of India (SBI). 2014a. The banker to every Indian: annual results FY 2012-13 [online], [cited 18 October 2014].
Available from Internet: https://www.sbi.co.in/portal/documents/44589/52273/1370069393224_ANALYST_PRESENTATION_FY13/f2805d68-9b0b-436d-a15b-e9619f2e35d6

State Bank of India (SBI). 2014b. SBI Branch Locator [online], [cited 18 October 2014]. Available from Internet: https:// www.sbi.co.in/user.htm?action=branchlocator

Sujatha, V.; Nalini, R. 2012. Assessing customer satisfaction of an Indian public sector using customer relationship management, in Proceedings of Conference Management Issues in Emerging Economies (ICMIEE), 17-18 August 2012, SASTRA Univerity, Thanjavur, Tamilnadu, India, 58-62.

Tuncikiene, Z.; Buzaite, G. 2010. Functional analysis in Public sector, Business, Management and Education 8(1): 185-200.

Tuncikiene, Z.; Grencikova, A.; Skackauskiene, I. 2014. Development of public-private partnership: managerial aspects, Business: Theory and Practice 15(1): 11-21. http://dx.doi.org/10.3846/btp.2014.02

Verma, S.; Chaudhuri, R. 2008. Meta-analysis of banking services in India: a customer centric approach, International Journal of Financial Services Management 3(3-4): 216-222. http://dx.doi.org/10.1504/IJFSM.2008.022548

Zeithaml, V. A.; Berry, L. L.; Parasuraman, A. 1996. The behavioral consequences of service quality, Journal of Marketing 60: 31-46. http://dx.doi.org/10.2307/1251929

Zvireliene, R.; Buciuniene, I. 2008. The role of relationship marketing dimensions in the customer retention, Business: Theory and Practice 9(4): 272-280. http://dx.doi.org/10.3846/1648-0627.2008.9.272-280

Rengaswamy NALINI is working as an Assistant professor in the Department of Business Administration, Cauvery College for Women, Tiruchirapalli, Tamilnadu, India. Her research area of interests is consumer behaviour and banking. She has ten years of collegiate teaching experience in finance, accounting and marketing. She has presented papers in national and international conferences and published papers in indexed journals.

Ramachandran AMUDHA. CMA and Dr is working as a Senior Assistant Professor in School of Management, SASTRA University, Thanjavur, India. She is also a fellow member in Institute of Cost Accountants of India. Her research area of interests is consumer behaviour, banking and financial services. She has twenty five years of collegiate teaching experience in finance, accounting, banking and marketing. She has presented papers in national and international conferences and published papers in Scopus indexed journals.

Venkatarayareddiar SUJATHA. Dr is working as a principal in Cauvery College for Women, Tiruchirapalli, Tamilnadu, India. Her research area of interests is consumer behaviour and human resource management. She has twenty eight years of collegiate teaching experience in human resource and marketing. She has presented papers in national and international conferences and published papers in indexed journals.

Rengaswamy RADHA is working as an Assistant professor in the Department of Maths, Cauvery College for Women, Tiruchirapalli, Tamilnadu, India. Her research area of interests is number theory and statistical applications. She has six years of collegiate teaching experience in mathematical statistics, real analysis and differential equations. She has published papers in indexed journals. 